\title{
ACORDOS DE NÁO PERSECUÇÃO CÍVEL: DESAFIOS E PERSPECTIVAS
}

\author{
NON-PERSECUTION AGREEMENTS: CHALLENGES AND PERSPECTIVES
}

\author{
Ana Paula Guimarães de Paula \\ Graduada em Direito pela Universidade Federal de Goiás \\ Assessora no Gabinete da Superintendência Geral do CADE \\ anaguimaraesdepaula@gmail.com \\ Luisa Campos Faria \\ Graduada em Direito pela Universidade de Brasilia \\ Analista de Politicas e Indústria II da CNI \\ luisacamposf@gmail.com
}

\section{RESUMO}

A Lei $n^{\circ} 13.964 / 2019$, conhecida como Pacote Anticrime trouxe importantes inovaçóes para o ordenamento jurídico brasileiro, com destaque para o chamado Acordo de Não Persecução Cível. Trata-se de nova previsão inserida na Lei de Improbidade Administrativa (Lei $\left.\mathrm{n}^{\circ} 8.429 / 94\right)$ que revoga a proibição de acordo, transação ou conciliação nas açóes respectivas. Nesse sentido, o presente artigo joga luz a uma série de Imbróglios envolvendo o gênero dos Acordos Decisórios, bem como as soluçóes que têm sido apresentadas para resolvê-los. A pertinência do debate justifica-se pela necessidade de garantia de maior segurança jurídica na utilização desses instrumentos, bem como em seu adequado aproveitamento para a proteção da própria Administração Pública.

Palavras-chave: Acordos Decisórios. Acordo Leniência. Lei Anticrime. Acordo de não persecução cível.

\section{ABSTRACT}

The Law No. 13.964 / 2017, known as the Anti-Crime Package, brought important innovations to the Brazilian legal system, with emphasis on the so-called Civil NonPersecution Agreement. This is a new provision included in the Administrative Improbity Law (Law No. 8,429 / 94) that revokes the prohibition on agreements, transactions or reconciliation in improbity's actions. In this sense, this article addresses a series of imbroglios involving the category Decision Agreements as well as the solutions that have been presented to resolve them. The relevance of the debate is justified by the need to guarantee greater legal certainty in the use of these instruments, as well as in their adequate use for the protection of the Public Administration itself.

Keywords: Decision Agreements. Leniency Agreement. Anticrime Law. Civil NonPursuit Agreement.

Dara de submissão: 10/07/2020 Data de aceitação: 06/10/2020 


\section{SUMÁRIO}

INTRODUÇÃO 1. A QUESTÃO DOS ACORDOS DECISÓRIOS NO DIREITO BRASILEIRO $1.1 \mathrm{O}$ que são Acordos Decisórios 1.2 A posiçẫo do Supremo Tribunal Federal $1.3 \mathrm{O}$ acordo de não persecução na ação de improbidade 2. ACORDOS DECISÓRIOS PARA A TUTELA DE BENS JURÍDICOS ATINENTES À ADMINISTRAÇÃO 2.1 Multiplicidade de bens jurídicos tutelados 2.2 Amplitude do controle. 2.3 Desafios específicos na execução de acordos de não persecução cível CONSIDERAÇÕES FINAIS

\section{INTRODUÇÁO}

A Lei no 13.964/2019, conhecida como Pacote Anticrime trouxe importantes inovaçóes para o ordenamento jurídico brasileiro, inserindo alteraçóes substanciais no Código Penal, Código de Processo Penal e Lei de Improbidade Administrativa. Nesta última, a novidade foi a revogação da norma que expressamente vedava a realização de acordo, transação ou conciliação nas açóes de improbidade, colocando em seu lugar autorizaçáo legal para a realização do Acordo de Não Persecução Cível.

Essa importante alteração traz à luz a necessidade de discussão sobre a utilização de Acordos Decisórios no Direito Brasileiro, que já foi alçada ao debate em nível constitucional, com o início de julgamento, pelo Supremo Tribunal Federal (STF), de conjunto de mandados de segurança que tratam da competência para aplicação de sançóes por diferentes autoridades em relação a condutas que já sejam objeto de Acordos com a Administração.

Reconhece-se, pois, uma tendência à proliferação de diferentes espécies desses Acordos, atraindo inclusive a competência da Defensoria Pública para sua celebraçáo. Isso se confirma pelo precedente firmado pelo STF na ADI 3.943/DF, em que restou assentada a legitimidade da atuação dessa instituição em defesa de direitos individuais relativos náo só aos hipossuficientes econômicos, mas, de forma mais ampla, aos hipossuficientes jurídicos ${ }^{1}$.

Tais elementos pintam um cenário de urgência para a discussão dos desafios que ainda cercam e atravancam a realizaçáo desses Acordos. Neste trabalho, escolhemos como recorte a aplicação de modalidade específica de Acordo Decisório - o Acordo de Não Persecução Cível - para a repressão de infraçōes em detrimento da Administração. Esse enfoque se justifica a partir da importância que a proteção da coisa pública representa na construção de regimes republicanos democráticos.

Nesse contexto, a primeira parte do artigo traça o panorama atual da utilizaçáo dos Acordos Decisórios no Direito Brasileiro, com o detalhamento da modalidade inserida em nosso ordenamento pelo pacote anticrime, além de apresentar as linhas de interpretação

BRASIL. Supremo Tribunal Federal (Tribunal Pleno). Açáo Direta de Inconstitucionalidade 3.943/DF Relatora: Cármen Lúcia, em 07/05/2015, DJe-154 em 06/08/2015. 
que têm sido privilegiadas pelo STF no debate sobre esse tema.

Na segunda seção, o objetivo é apresentar os desafios que ainda se colocam para a realização desses Acordos para a repressão a infraçóes que tenham como sujeito passivo a Administração Pública. Para tanto, destacamos os atributos relacionados às noçóes de Administração e Interesse Público que acrescentam um maior nível de complexidade à implementação desses acordos. A seguir, são apresentados os principais obstáculos para a celebração de Acordos de Não Persecução Cível e as soluçóes que tem sido apresentadas por atos normativos dos legitimados à celebração dos Acordos.

A conclusão destaca que nosso ordenamento não comporta uma solução ideal, capaz de neutralizar todos os obstáculos que cercam a realização do Acordo de Não Persecução Cível. Não obstante, pensar em formas de amenizar eventuais conflitos é medida urgente e necessária para que esse instrumento, e os Acordos Decisórios em geral, não restem relegados ao plano de meros apetrechos de gestão de interesses privados, impedindo que o Poder Público se beneficie das vantagens associadas a celebração desse tipo de negócio jurídico.

\section{A QUESTÁO DOS ACORDOS DECISÓRIOS NO DIREITO BRASILEIRO}

Os Acordos Decisórios são hoje importante instrumento da chamada justiça consensual -modelo de justiça que vem ganhando cada vez mais espaço no ordenamento brasileiro, tendo sido amplamente adotado pelo Código de Processo Civil de $2015^{2}$.

Seu surgimento está inicialmente ligado a atuação regulatória do Estado que, reclamado a intervir em setores de alta complexidade técnica, necessitou estabelecer formas de aplicação de sançóes e regulação setorial diferentes das sançóes tradicionais conhecidas no âmbito do direito administrativo sancionador. Cita-se, a esse exemplo, o caso dos Acordos de Leniência Antitruste, previstos na Lei $n^{\circ} 12.529 / 2011$ que foram idealizados como um meio para viabilizar investigaçóes sobre infraçóes contra a ordem econômica, cuja obtenção de provas, dificilmente, seria possível a partir de esforços unilaterais do Poder Público.

Ocorre que a utilização desses instrumentos não ficou circunscrita a essa atuação regulatória. Assim é que os Acordos Decisórios passaram também a ser utilizados como forma de resolução de conflitos em que o modelo tradicional de jurisdição não se mostrava capaz de, adequadamente, oferecer solução aos interesses envolvidos.

2 O Código de Processo Civil de 2015 (Lei n ${ }^{\circ} 13.105$ de 16 de março de 2015) no $\$ 3^{\circ}$ de seu art. $3^{\circ}$ traz que "A conciliação, a mediação e outros métodos de solução consensual de conflitos deverão ser estimulados por juízes, advogados, defensores públicos e membros do Ministério Público, inclusive no curso do processo judicial.". Além disso, estabelece o art. 344 que "Se a petição inicial preencher os requisitos essenciais e não for o caso de improcedência liminar do pedido, o juiz designará audiência de conciliação ou de mediação com antecedência mínima de 30 (trinta) dias, devendo ser citado o réu com pelo menos 20 (vinte) dias de antecedência”, tornando obrigatória a realização da audiência antes do julgamento do feito, que só deverá ser dispensada, nos termos do CPC de 2015, caso ambas as partes em petição inicial e contrarrazóes se manifestem pela não realização da audiência. 
É o caso da celebração de Termos de Ajustamento de Conduta pelos legitimados em caso de dano ambiental, visto que a atuação judicial clássica - com a instauração do processo para conhecimento, prolação de sentença condenatória e posterior fase de execução - poderia ser incompatível com a necessidade de recuperação tempestiva de recursos naturais ou mesmo a prestação de atividades materiais - execução específica - de certas obrigaçóes impostas ao compromitente.

A possibilidade de utilização desses instrumentos atende a diversos objetivos, tais como maior celeridade na resolução de litígios administrativos e judiciais; maior efetividade na aplicação de sançóes aos particulares; maior nível de legitimidade na atuação do Estado.

É nesse contexto de escalada de importância e de utilização desses negócios jurídicos em nosso direito que enfrentaremos nas sessóes seguintes questóes como o que se entende por acordos decisórios e como, atualmente, se posiciona nossa Corte Constitucional quanto a aplicação desses métodos.

\subsection{O que são os Acordos Decisórios?}

Entendemos por Acordos Decisórios os instrumentos consensuais e negociais ofertados pelo Poder Público para que particulares - pessoas físicas e/ou jurídicas - que infrinjam o ordenamento possam voltar à conformidade, com a aplicação de sançóes em detrimento da conduta irregular acompanhada da disponibilizaçáo de determinados incentivos à colaboração do particular.

Entendida a categoria de Acordos Decisórios como um gênero, é possível identificar pelo menos 05 (cinco) espécies previstas em nosso ordenamento: Acordo de Leniência Antitruste, instituído por meio da Lei $\mathrm{n}^{\circ}$ 12.529/2011; Acordo de Leniência Anticorrupção, instituído por meio da Lei ${ }^{\circ} 12.846 / 2013$; Acordo de Leniência Penal, cuja previsão normativa encontra-se nas leis que estabelecem as competências do Ministério Público, a partir de uma interpretação sistemática das funçóes constitucionais do órgão; Acordo de Leniência do Sistema Financeiro Nacional, instituído pela Lei $n^{\circ}$ 13.506/2017, destinado aos crimes financeiros e cuja celebração compete ao Banco Central (BACEN) e ao Conselho de Valores Monetários (CVM); Acordo de Não Persecução Cível, introduzido pela Lei $n^{\circ} 13.964 / 2019$ na Lei de Improbidade Administrativa e cuja competência para celebração é da Fazenda Pública e/ou do Ministério Público.

Destaque-se que, por serem instrumentos relativamente novos em nosso ordenamento, ainda não existe uma sistematização doutrinária ou jurisprudencial consolidadas quanto ao conceito e modalidades desses instrumentos. Essa falta de sistematização e arcabouço teórico é ainda um dos desafios que se impóem à utilização mais ampla desses institutos, como se verá adiante.

\subsection{A posição do Supremo Tribunal Federal}


A 2a Turma do Supremo Tribunal Federal, em maio de 2020, começou o julgamento conjunto de quatro Mandados de Segurança ${ }^{3}$ que questionam a possibilidade de aplicação de determinadas sançóes por parte do TCU - mais precisamente, a aplicação de declaração de inidoneidade a empresas punidas por fraudes licitatórias referentes às obras da Usina de Angra III. A particularidade do caso reside no fato de que as empresas já haviam firmado Acordos de Leniência com outras instituiçôes, como MPF, AGU, CADE, CGU.

Embora o julgamento, quando da redação deste trabalho, ainda não tenha obtido um desfecho, o voto exarado pelo relator, Ministro Gilmar Mendes, jogou luz a uma série de problemas decorrentes da ausência de coordenação entre os diversos agentes e órgãos públicos, além de trazer uma visáo propositiva da matéria.

Para o Relator, um primeiro ponto de atenção é quanto ao fato de que algumas modalidades de Acordos Decisórios são instrumentos importantes e estratégicos no que concerne a descoberta, desmantelamento e punição de infraçóes contra bens jurídicos de titularidade difusa - caso da ordem econômica, da coletividade de consumerista, do meio ambiente, entre outros.

No voto, o Relator utiliza como exemplo os Acordos de Leniência para infraçóes contra a ordem econômica, tecendo considerações aplicáveis a todas as espécies de Acordos Decisórios. Nesse cenário, quando falamos de condutas colusivas - como é o caso de cartéis e fraudes à licitação e cartel, por se tratarem de infrações de difícil descoberta e comprovação de materialidade, muitas vezes os crimes só são punidos por meio da realização deste tipo de acordo.

Para que tais institutos funcionem, o Estado oferece prêmios e regalias para que consiga punir condutas que, de outro modo, não seriam passíveis de descoberta. Espera-se a partir de programas de leniência e através do fechamento deste tipo de acordo que um dos autores da conduta confesse sua participação no ilícito e, com isso, as autoridades responsáveis possam iniciar a investigação relativa a outros agentes, desmantelar o esquema e punir todos os envolvidos devidamente.

Ainda utilizando o exemplo dos Acordos de Leniência, primordial entender, no entanto, que não há porque uma empresa confessar participação num ilícito se esta for receber as mesmas puniçóes aplicáveis às demais participantes da infração. Tampouco é vantajoso a uma empresa entregar-se quando não é possível mensurar as todas possíveis perdas a serem sofridas, de maneira com que permanecer vulnerável à aplicação de penalidades por entes diversos traz um aspecto de insegurança jurídica e dificulta a realização dos acordos.

Assim, de forma análoga ao que ocorre num contrato, a empresa compromete-se em colaborar com o Poder Público, ao passo que este mantém a suspensão circunstancial condicionada das sanções aplicáveis. Em algumas hipóteses, a suspensão das sanções torna-se condição de cumprimento do próprio acordo de colaboração.

Ocorre que, pelo modo como atualmente estão estruturados os Acordos Decisórios no

3 MS 35.435, MS 36.173, MS 36.496 e MS 36.526 
país, mesmo que a empresa consiga negociar e fechar acordo com um órgão, esta pode se tornar vulnerável à ação de diversos outros, que, inclusive poderão dispor de provas capazes de condená-las, advindas do intercâmbio de documentos com órgão no qual o acordo decisório foi fechado.

Neste contexto, identifica-se uma falha na disciplina atual dos Acordos Decisórios: a dificuldade em garantir segurança jurídica mínima aos particulares para a celebração de tais negócios jurídicos em um contexto de variadas espécies de Acordos e múltiplas autoridades competentes. Isso tudo para evitar que os interessados na realizaçáo de Acordos Decisórios não sejam prejudicadas pela multiplicidade dos instrumentos previstos pelo ordenamento jurídico brasileiro, o que esvaziaria a utilidade desses importantes instrumentos.

No caso em julgamento pelo STF, o voto do relator sustenta que, em nosso orndenamento, o regime de responsabilização das pessoas jurídicas é duplo, de modo que os atos lesivos à Administração Pública definidos no art. $5^{\circ}$ da Lei $n^{\circ} 12.843 / 2013$ podem ensejar (i) responsabilidade administrativa (nos termos dos Capítulos III e IV da mesma lei, exercido pela CGU), e (ii) responsabilidade judicial (nos termos do Capítulo VI, os múltiplos regimes de responsabilização judicial podem ser exercidos por meio da AGU).

Ainda para a hipótese específica trazida a julgamento pelo STF, sustenta-se que a penalização que pode ser exercida pelo TCU advém da Lei $n^{\circ} 8.443 / 1992$, e em tese continuaria válida ainda que os mesmos fatos tenham sido objeto de acordo com a CGU ou a AGU, nos termos da Lei $n^{\circ} 12.843 / 2013$. O que o voto do relator observou, desta feita, é que os ilícitos admitidos à CGU e à AGU e os fatos que constituem o objeto da apuração feita a título de Controle Externo pelo TCU são os mesmos, o que gera um debate acerca não apenas da ocorrência de bis in idem, mas que, pior que isso, coloca em cheque a efetividade do programa de leniência aderido pelas empresas.

Tal ameaça resulta justamente da ausência de coordenação entre os regimes de responsabilidade cível e administrativa, e a multiplicidade dos instrumentos existentes em cada uma destas searas. Segundo asseverou o Ministro, a lógica do modelo de justiça negocial seria de instituir um rígido regime de colaboração, e conquanto uma parte se compromete com o fornecimento de provas necessárias à punição de outros agentes, a outra parte, constituída pelo Poder Público deve se ater às puniçóes negociadas, de modo com que, ainda, seja garantido às partes a possibilidade de pagamento das penas pecuniárias acordadas. De acordo com o Ministro, no entanto, a declaração de inidoneidade poderia comprometer a possibilidade de que a empresa pudesse honrar com o pagamento acordado.

Assim, embora a sanção de inidoneidade pudesse ser imposta pelo TCU, nos termos da Lei $n^{\circ} 8.443 / 1992$, a aplicação desta sanção resultaria em verdadeira ineficácia da cláusula do Acordo firmado que mitiga as sançóes administrativas, esvaziando a força normativa do art. 17 da Lei $\mathrm{n}^{\circ} 12.846 / 2013$, pois os efeitos práticos para a empresa ora signatária do acordo seriam os mesmos. Nesse contexto, embora a celebraçáo do Acordo com outros órgãos (CGU e AGU no caso analisado) não obste a apuração pelos mesmos fatos por parte do TCU, as sançóes devem sempre levar em conta os impactos possíveis nos acordos já efetuados com a Administração.

Fato é que o problema relativo á multiplicidade de Acordos Decisórios, e que também 
vulnera a novel modalidade do Acordo de Não Persecução Cível, há muito tem ameaçado $^{4}$ a efetividade dos programas que visam mitigar puniçóes em troca de informaçóes que permitam a aplicação de sançóes a outros agentes bem como o desmantelamento de condutas que possam ser danosas à Administração Pública e à Ordem Econômica, de maneira que, em não havendo uma coordenação entre os agentes, é bastante feliz que o judiciário possa, por meio de tais análises, traçar os limites de atuação destes órgãos, que possuem competências distintas, mas que nestes casos aparentemente encontram-se sobrepostos.

Em síntese, o que a Corte Constitucional sinaliza nesse julgamento é a preocupação que nosso ordenamento deve ter com a garantia de transparência, previsibilidade e segurança jurídica aos administrados acerca dos possíveis resultados advindos da celebração de Acordos Decisórios. Trata-se de passo necessário para que a Administração Pública e os jurisdicionados possam, cada vez mais, se beneficiar dos programas e colaboraçóes fechados nos mais diversos órgãos.

É importante se atentar para todos os imbróglios judiciais advindos dos Acordos de Leniência porque estes, mais antigos que o recém instituído Acordo de Não Persecução Cível, já tiveram tempo para que pudessem ser objeto de análise pelos Tribunais. Nesse sentido, é bastante provável que os problemas e as inseguranças jurídicas relativas aos demais Acordos Decisórios tenham soluçóes que sirvam de farol às complicaçóes que possam surgir quando da realização de Acordos de Não Persecução Cível. A seção seguinte destina-se, nesse contexto, a apresentar as particularidades desse novo instituto.

\section{$1.3 \mathrm{O}$ acordo de náo persecução na ação de improbidade}

A Lei $n^{\circ} 13.964 / 2019$ (Pacote Anticrime) representou um giro paradigmático para a interpretação e aplicação da Lei de Improbidade Administrativa (Lei nº 8.429/1992). Isso porque, antes da mudança legislativa, a lei impedia a realização de quaisquer acordos na ação civil pública que tratasse de improbidades.

Para entender essa mudança, vale traçar uma breve evolução de diversas leis penais instituíram a possibilidade de realizaçáo de acordo em crimes de menor potencial ofensivo. É o caso da Lei $n^{\circ} 9.099 / 95$, que instituiu a possibilidade de realização de transação penal; em sentido semelhante, a Lei n ${ }^{\circ} 12.850 / 2013$, a Lei de Organizaçôes Criminosas, prevê a possibilidade de realização de um acordo de colaboração premiada, que ao atingir requisitos mínimos poderia afastar a aplicação de pena; posteriormente, a Lei n ${ }^{\circ} 12.846 / 2013$ (Lei Anticorrupção), que prevê a realização de Acordos de Leniência com relação a atos contra a administração pública; mais recentemente, em 2018, com a inclusão por meio da

\footnotetext{
4 Um caso bastante emblemático diz respeito ao Acordo de Leniência da empresa holandesa SBM Offshore, que, quando inicialmente celebrado junto à CGU previa a "quitação integral quanto aos prejuízos". Tal cláusula, porém, não foi aceita pela 5a Câmara de Coordenação e Revisão do MPF nem pelo TCU, de maneira com que a empresa precisou reiniciar as negociaçóes. A empresa terminou por ressarcir o erário em cerca de R\$1,2 bilhão, sem que fosse concedida a garantia da quitaçáo integral.

5 Ate a edição da Lei $n^{\circ}$ 13.964/2019, o art. 17 da Lei de Improbidade, em seu art. $1^{\circ}$ estabelecia ser "[...] vedada a transação, acordo ou conciliaçáo nas ações de que trata o caput.".
} 
Lei $\mathrm{n}^{\circ}$ 13.655/2018 do novo art. 26 da Lei de Introdução às Normas do Direito Brasileiro (LINDB), qualquer prerrogativa pública poderia ser objeto de resolução consensual.

Mencione-se que antes da edição do Pacote Anticrime, o Conselho Nacional do Ministério Público tentou resolver a questão da realização de transaçóes em açóes de improbidade por meio de uma resolução. Trata-se da Resolução no 179/2017 que permitia a celebração de Termo de Ajustamento de Conduta (TAC) em processos de improbidade. Além desse instrumento, havia outros meios consensuais de resolução de conflito - como os termos de ajustamento de gestão (TAG) e os Acordos Substitutivos (AS) - , fundados no próprio texto constitucional que assegura a solução pacífica das controvérsias como valor fundante da república (Constituição, preâmbulo), além de princípio que rege a atuação do Brasil nas relações internacionais (Constituição, art. $4^{\circ}$, inciso VII).

É na confluência dessa evolução histórica e legislativa que o Pacote Anticrime insere em nosso direito o Acordo de Não persecução Cível. Tal acordo tem como intuito impedir o início ou a continuidade de uma ação de improbidade desde que sejam firmados alguns compromissos ante a Administração (diretamente com a Fazenda Pública interessada ou com o Ministério Público), garantindo por meio da aplicação de sançóes mitigadas que essas sejam mais efetivas, conquanto são consensuais.

De Natureza Jurídica bifronte, reunindo características intrínsecas tanto à Colaboração Premiada quanto aos Termos de Ajustamento de Conduta, abarca desse modo tanto questóes relativas às negociaçóes de sançóes e ilícitos, versando, portanto, acerca de aspectos eminentemente materiais, quanto produz efeitos que estabilizam relaçóes processuais, impedindo o início ou curso de açôes. Há autores que, de modo a tentar diferenciar o Acordo de Não Persecução da Leniência, chegam a afirmar que quando celebrado na esfera administrativa, receberia a nomenclatura de Acordo de Leniência, mas quando celebrado em juízo, receberia a nomenclatura de Acordo de Não Persecução Cível ${ }^{6}$

Apresentada essa definição de cunho mais doutrinário, alguns aspectos do Acordo de Não Persecução Cível merecem análise destacada, a saber: (i) a para a legitimidade ativa; (iii) momento de realização; (iii) sujeitos que podem ser beneficiados.

Quanto à legitimidade ativa, não há previsão expressa de quem seria a entidade competente para a celebraçáo desses Acordos, de modo que a interpretaçáo mais razoável parece ser aquela que estende à pessoa jurídica interessada - ou seja, aquela lesada pela prática - e ao Ministério Público a prerrogativa para tanto, já que ambos os sujeitos possuem legitimidade para a propositura dessas demandas. Já aqui nota-se um campo fértil para conflitos no caso de ausência de consenso das autoridades quanto à realização de determinado acordo. Desse modo, uma das perguntas que será enfrentada pelo trabalho é justamente quanto à necessidade de concordância dos dois legitimados para a consecuçáo do Acordo de Não Persecução Cível.

Em relação ao momento de realização, o Acordo de Não Persecução Cível, conforme es-

OSÓRIO, Fábio Medina. "Natureza jurídica do instituto da náo persecuçáo cível previsto na lei de improbidade administrativa e seus reflexos na lei de improbidade empresarial". 2020. 
tatuído, pode ser fechado tanto em etapas judiciais quanto em etapas extrajudiciais - ou seja, tanto no curso da ação quanto no curso de inquéritos cível, penal ou administrativo. De acordo com Luciano Ferraz ${ }^{7}$, passada a contestação, incluindo quando a ação se encontrar em grau de recurso ou na etapa do cumprimento de sentença, as partes legitimadas poderão fazer uso de outros instrumentos, tais como os termos de ajustamento de conduta (art. 5, $\$ 6^{\circ}$ da Lei $n^{\circ} 7.347 / 85$ ), os acordos substitutivos (art. 26 da LINDB) ou, ainda, os compromissos processuais (art. 27 da LINDB).

O último elemento destacado diz respeito aos sujeitos que podem se beneficiar desses Acordos, matéria expressamente tratada na nova redação dada à Lei $n^{\circ} 8.429 / 92$, tem-se que os Acordos de Não Persecução poderiam tanto ser firmados por pessoas físicas quanto por pessoas jurídicas.

Em síntese, tratando-se de instituto novo, certo é que muitas dúvidas acerca de sua aplicação devem surgir, a se somarem aos não poucos problemas que já cercam a aplicação dos Acordos Decisórios, de forma geral, em nosso ordenamento. As seçóes seguintes deste trabalho buscarão enfrentar as problemáticas já apresentadas, assim como outras questóes específicas, atinentes à celebração do Acordo de Não Persecução Cível.

\section{ACORDOS DECISÓRIOS PARA A TUTELA DE BENS JURÍDICOS ATINEN- TES À ADMINISTRAÇÃO}

De acordo com o conceito sugerido na primeira parte deste trabalho, entendemos por Acordos Decisórios os instrumentos consensuais e negociais ofertados pelo Poder Público para que particulares - pessoas físicas e/ou jurídicas - que infrinjam o ordenamento possam voltar à conformidade, com a aplicação de sançóes em detrimento da conduta irregular acompanhada da disponibilização de determinados incentivos à colaboração do particular.

Tais acordos têm especial aplicação no campo da atividade regulatória do Estado, voltada ao controle de setores altamente técnicos e complexos ${ }^{8}$. Nesses casos, a infração cometida pelo particular poderá ter como bem jurídico violado tanto interesses públicos quanto interesses privados. Um exemplo torna a questão mais clara: a Lei $\mathrm{n}^{\circ} 7.437 / 1985$ permite aos "órgãos públicos legitimados" (art. $5^{\circ}, \$ 6^{\circ}$ ) tomar dos interessados "compromisso de ajustamento de sua conduta às exigências legais, mediante cominaçóes”. Trata-se de um exemplo típico de Acordo Decisório, nesse caso, voltado à tutela dos bens previstos no art. $1^{\circ}$ da Lei da Ação Civil Pública, genericamente referidos como todo e qualquer direito ou interesse coletivo (direitos difusos, coletivos em sentido estrito e individuais homogêneos, ex vi do art. 81 do CDC).

A violação a esses direitos coletivos pode lesar um interesse estritamente particular, como na

FERRAZ, Luciano. "Acordos de não persecução na improbidade administrativa - o início, o fim e o meio”. 2020.

8 OLIVEIRA, Rafael Carvalho Rezende. Curso de Direito Administrativo, 2020, p. 555. 
hipótese de uma coletividade de consumidores prejudicada pela colocação no mercado de um produto com publicidade enganosa. Nessa situação, a celebração do TAC não envolveria a proteção a um interesse público, tomada essa expressão em seu sentido mais estrito.

Situação diferente seria a realização de um TAC com um particular que depredou um bem tombado ou com um ente municipal que náo esteja oferecendo adequadamente um serviço público de sua competência. Nesses dois exemplos temos, com diferentes gradaçôes, acordos que tratam diretamente de interesses públicos, ou seja, acordos que tutelam a Proteção da Administração Pública.

É justamente quando utilizados para a tutela da Coisa Pública - ou seja, quando a infração cometida pelo particular tem como vítima a Administração Pública - que a aplicação dos Acordos Decisórios encontra seus maiores desafios, especialmente em face de três aspectos: (i) a multiplicidade de bens jurídicos tutelados; e (ii) a amplitude do controle exercido sobre a Administração; (iii) a noção de indisponibilidade do interesse público.

\subsection{Multiplicidade de bens jurídicos protegidos}

O primeiro elemento destacado foi abordado pelo STF no julgamento, ainda náo finalizado, de um conjunto de Mandados de Segurança que questionam a possibilidade de aplicação de penalidade pelo TCU a conduta que já é objeto de acordo de leniência firmada entre o particular e o Conselho Administrativo de Defesa Econômica (CADE). Na ocasião, a Corte Suprema reafirmou a competência do Tribunal de Contas, reconhecendo que cada uma das entidades possui seara de atuaçáo própria, vocacionada a proteçâo de bens jurídicos diversos.

Com efeito, quando falamos em prejuízo à Administração Pública referimo-nos a violação de mais de um bem jurídico. Basta resgatar aqui a tradicional diferenciação, feita na doutrina administrativa, entre interesse público primário - que consubstancia a satisfação de interesses coletivos - e interesse público secundário - que tutela o interesse do Estado enquanto sujeito de direitos e obrigaçôes, especialmente em sua dimensão pecuniária?.

Essas duas dimensóes são apenas o ponto de partida para o reconhecimento dos inúmeros interesses que são violados quando se praticam infraçoos em detrimento da Máquina Pública. A verdade é que a própria noção de interesse público, um conceito jurídico indeterminado, está sempre sujeita a novas interpretaçóes, o que amplia o espectro de situaçōes que se caracterizam como violação ao interesse da Administração.

Em síntese do tema, Rafael Oliveira ${ }^{10}$ afirma:

(...) em verdade, nunca existiram um único “interesse público” tampouco um interesse privado, concebidos abstratamente e de forma cerrada. Muito ao contrário, em uma sociedade pluralista, existem

\footnotetext{
OLIVEIRA, Rafael Carvalho Rezende. Curso de Direito Administrativo, 2020, p. 47.

10 OLIVEIRA, Rafael Carvalho Rezende. Curso de Direito Administrativo, 2020, p. 49.
} 
diversos interesses públicos e privados em constante conexão, de modo que, naturalmente, poderão emergir eventuais conflitos entre interesses considerados públicos (ex.: a criação de uma hidrelétrica e a necessidade de desmatamento de área florestal de conservaçáo permanente), entre interesses denominados privados (ex.: o direito à intimidade e o direito à liberdade de expressão) e entre interesses públicos e privados (ex.: a servidão administrativa de passagem estabelecida em imóvel particular para utilização de ambulâncias de determinado nosocômio público).

Neste ponto, um exemplo prático ajuda a entender: quando um grupo de particulares combina preços para propostas em determinado procedimento licitatório e subornam um agente da entidade pública licitante para serem favorecidos no certame, é possível vislumbrar dano a pelo três bem jurídicos: à ordem econômica, em razão da prática de cartel; à probidade administrativa, diante da frustração à lisura da licitação; e à integridade da Administração, em razão da prática de corrupção. Isso sem mencionar a repercussão penal das condutas.

Cada um desses bens, no modelo organizatório dos Poderes Republicanos disposto pelo Constituinte de 88, está inserido na competência de uma (ou mais de uma) entidade diversa, daí os imbróglios envolvendo a competência para a celebração de Acordos Decisórios e a discussáo quanto a imposição de penalidades ao agente por condutas que já sejam objeto de leniência com a Administração.

Isso porque o bem jurídico tutelado no âmbito da atuação de uma agência reguladora como o CADE, a saber, a integridade da ordem econômica, não é o mesmo tutelado pelo Tribunal de Contas, incumbido da fiscalização contábil, financeira, orçamentária, operacional e patrimonial do Estado, que, por sua vez, também é diverso da tutela da probidade da administração, promovida no âmbito do Ministério Público.

A Administração Pública guarda em seu seio um imbricado arranjo de valores e bens jurídicos, de modo que, dificilmente, a violação a um deles poderá ser isolada, sem repercussão em outros bens. E é nesse reduto de bens e interesses tangentes e inter-relacionados que deve atuar a autoridade competente para a pactuação de acordos decisórios. Trata-se de terreno fértil para o surgimento de conflitos, tais como, a definição de competências de atuação, a coordenação entre as penas aplicadas, o compartilhamento de provas e a organização da atividade investigativa.

Nesse contexto, ainda se eleva como enorme desafio para a implementação dos acordos decisórios em infraçóes cometidas contra a Administração a necessidade de coordenação entre as autoridades competentes, sob pena de descrédito e inefetividade desses instrumentos quando utilizados para a repressão de infraçóes em desfavor da coisa pública.

\subsection{Amplitude do controle}

O segundo aspecto que dificulta a realização dos Acordos Decisórios em infrações contra a Administraçáo apresenta-se como espécie de desdobramento do primeiro elemento 
trazido: em razão da multiplicidade de bens jurídicos que compõem a coisa pública, há diversas espécies de controle sobre esses interesses.

Em acréscimo a essa perspectiva, devemos mencionar também que a amplitude do controle sobre o Poder Público deve-se ainda ao regime democrático preconizado pela nossa Constituição, que impóe como dever inafastável a transparência na condução dos assuntos do Estado.

Com efeito, nosso ordenamento comporta diversos tipos de controle sobre a Administração: controle interno, controle externo, controle social e controle jurisdicional, para citar apenas algumas modalidades. A diversidade nas formas de controle é corolário do princípio republicano, que repousa, dentre outros, sobre o fundamento do inconformismo social com a impunidade dos agentes públicos' e da 'ideia de responsabilidade dos governantes' ${ }^{11}$.

Com efeito, conforme assente na interpretação dada pelo Supremo Tribunal Federal, o núcleo essencial de nosso Estado é composto por três princípios: o democrático, o federativo e o republicano. A preservação desse núcleo duro exige a presença de três elementos: a eletividade dos governantes, a temporariedade dos mandatos e a Direito Constitucional e a responsabilidade dos agentes públicos ${ }^{12}$.

Ocorre que a responsabilidade dos agentes públicos só se concretiza quando há controle sobre a atividade administrativa, com vigilância sobre os atos públicos e previsão de hipóteses de responsabilidade. Nesse toar, a amplitude das formas de controle estipulada pelo Constituinte de 1988 não é senão uma estratégia para conferir a maior eficácia possível ao princípio republicano.

Sem prejuízo desse preceito fundamental à ideia de Estado Democrático de Direito, também a amplitude do controle sobre a Administração deve ser equacionada de modo a não representar obstáculo a implementação de medidas consensuais e participativas na repressão aos ilícitos praticados contra o Poder Público.

Defender o contrário é fechar as portas para a utilização de uma importante estratégia para adequação de práticas lesivas ao poder público, ou seja, diminuir os instrumentos que o ordenamento jurídico disponibiliza justamente quando se trata de um bem essencial ao Estado Democrático: o interesse público.

Pensar sobre os obstáculos que ainda dificultam a utilização dos Acordos Decisórios nas infraçōes em desfavor da Administração é um passo necessário para que tais acordos não se consolidem como meros instrumentos de gerenciamento de interesses privados, servindo, outrossim, à proteção da República.

$11 \quad$ BRASIL Supremo Tribunal Federal (Tribunal Pleno). ADI 4764. Relator: Min. Celso De Mello, Relator p/ Acórdão: Roberto Barroso, julgado em 04/05/2017, DJe-178 em 15/08/2017.

12 BRASIL. Supremo Tribunal Federal (Tribunal Pleno). Açáo Direta de Inconstitucionalidade 4362, Relator: Dias Toffoli, Relator(a) p/ Acórdão: Roberto Barroso, 09/08/2017, DJe-021, publicado em 06/02/2018. 


\subsection{Indisponibilidade do interesse público}

A Indisponibilidade, pela Administração, do Interesse público, na clássica lição de Celso Antônio Bandeira de Melo, significa que ${ }^{13}$ :

sendo interesses qualificados como próprios da coletividade - internos ao setor público -, não se encontram à livre disposição de quem quer que seja, por inapropriáveis. $\mathrm{O}$ próprio órgão administrativo que os representa não tem disponibilidade sobre eles, no sentido de que lhe incumbe apenas curá-los - o que é também um dever - na estrita conformidade do que predispuser a intentio legis.

Foi com fulcro nessa concepção que, por longo tempo, a possibilidade de negócios jurídicos consensuais pela Administração Pública na resolução de seus litígios - aqui fala-se tanto dos Acordos Decisórios, quanto de qualquer transação pretendida pela administração - permaneceram reputados como incompatíveis com o Regime Jurídico-Administrativo. Ocorre que, sobretudo nas últimas duas décadas, nota-se marcada tendência - legislativa, doutrinária e jurisprudencial - de desconstrução dessa impossibilidade de resoluções consensuais como corolário do princípio da indisponibilidade.

Legislativamente, o marco dessa mudança pode ser identificado na Lei $n^{\circ}$ 9.307/2015 (Dispóe sobre a arbitragem), alterada pela Lei ${ }^{\circ} 13.129 / 2015$, que passou a prever, em seu art. $1^{\circ}, \$ 1^{\circ}$, expressamente, a possibilidade de que a Administraçáo Pública recorra à via arbitral para "dirimir litígios relativos a direitos patrimoniais disponíveis" ${ }^{14}$. Muito embora antes do referido diploma, já houvesse previsão legal para a resolução amigável de conflitos e divergências envolvendo contratos com o Poder Público - Lei n ${ }^{\circ} 8.987 / 95$; Lei $n^{\circ}$ 9.472/97; Lei ${ }^{\circ}$ 9478/97; Lei ${ }^{\circ}$ 10.233/2001; Lei n ${ }^{\circ} 10.343 / 2002$; Lei n 132.815 -, a nova lei merece destaque por demarcar que nem todos os direitos da Administração serão indisponível, cabendo, quanto àqueles que não o sejam, a possibilidade de submissão à arbitragem.

$\mathrm{Na}$ jurisprudência, podemos destacar o Recurso Especial n ${ }^{\circ}$ 904.813/PR, de lavra do $\mathrm{STJ}^{15}$, em que se consignou que a controvérsia acerca da impossibilidade de instituição do juízo arbitral para controvérsias envolvendo direitos indisponíveis, não alcança conflitos relativos a interesses disponíveis como a manutenção do equilíbrio econômico-financeiro de um contrato.

Já na doutrina, cita-se Diogo de Figueiredo ${ }^{16}$, para quem "a consensualidade vem se sobressaindo como uma válida alternativa para incrementar a eficiência administrativa (...)”,

\footnotetext{
13 MELlO, Celso Antônio Bandeira de. Curso de direito administrativo. São Paulo: Malheiros. 2012. p. 53-56.

14 BRASIL. Lei no 9.307, de 23 de setembro de 1996. Dispóe sobre a arbitragem. Diário Oficial da União, Brasília, DF.

15 BRASIL. Superior Tribunal de Justiça. REsp 904.813/PR. Rel. Ministra Nancy Andrighi, terceira turma, julgado em 20/10/2011, DJe 28/02/2012

16 MOREIRA NETO, Diogo de Figueiredo. Curso de direito administrativo. Rio de janeiro: Forense, 2005. V. 15
} 
constata-se, nesse cenário, uma "profusão de novas relaçôes negociadas em que se privilegia o consenso como método para o mais fácil, mais célere e menos dispendioso atingimento de interesses públicos específicos postos a cargo do Estado". Ademais, também a doutrina processual contribui com o debate, como na lição de Leonardo Carneiro da Cunha, para quem "A indisponibilidade do direito material não implica necessária indisponibilidade do direito processual" 17 .

Em síntese, essas evoluções doutrinárias, legislativas e jurisprudenciais trazem as seguintes premissas para o ordenamento: (i) nem todo interesse do Estado é um interesse público; (ii) dentre aqueles interesses do Estado que sejam considerados públicos, haverá, ao menos, duas categorias, os interesses disponíveis e os indisponíveis; (iii) mesmo em relação aos direitos indisponíveis, não se pode dizer que à indisponibilidade do direito material corresponda necessária indisponibilidade de direito processual.

É na confluência desses fenômenos que ao princípio da indisponibilidade do interesse público tem sido conferida nova interpretação, pela qual nem todo tipo de relaçáo negociação envolvendo os interesses do Estado é vedada. Isso porque, nem sempre, a solução litigiosa será aquela que melhor atende ao interesse público ${ }^{18}$ - é possível até mesmo afirmar que, em certos casos, a existência do litígio representa prejuízo tanto ao interesse público primário quanto ao secundário. Nesse toar, desconstrói-se a antítese entre indisponibilidade do interesse público e à vedação a qualquer tipo de transigência pela administração o que dá força, portanto, ao surgimento e desenvolvimento dos Acordos Decisórios como técnica de resolução de conflitos do Administração.

\subsection{Desafios específicos na execução do acordo de náo persecução cível e as soluçóes propostas por atos normativos dos legitimados ativos}

A inserção do Acordo de Não-Persecução Cível veio acompanhada de questionamentos ainda não plenamente respondidos. Por exemplo, pode um dos legitimados transacionar com o infrator sem a participação da outra autoridade competente? Haveria a necessidade de celebração de Acordos individuais com cada um dos legitimados? como definir limites para os benefícios e sançóes imputados ao infrator? É possível dispensar um ou alguma das modalidades de pena previstas na lei, que permite a cumulação de sançôes?

Com a finalidade de aplicar o instituto do Acordo de Não Persecução Cível, alguns entes

17 CUNHA, Leonardo Carneiro da. A Fazenda Pública em juízo. Rev., atual e ampl. Rio de Janeiro: Forense, 2017.

18 Acerca da Justiça consensual que possuem a Administraçáo como parte, vale lembrar os ensinamentos de Juarez Freitas: "Todavia, os acordos prudentes e idôneos se ajustam sobejamente ao Direito Administrativo, quando consubstanciam: (a) compromissos eficientes e eficazes, prestimosos à implementação das políticas públicas, em tempo útil; (b) compromissos promotores da probidade; (c) compromissos que não invadem a esfera do indisponível; (d) compromissos de comprovados benefícios sistêmicos líquidos, com avaliaçáo prévia de impactos multidimensionais. FREITAS, Juarez. Direito administrativo não adversarial: a prioritária solução consensual de conflito. Revista de Direito Administrativo, Rio de Janeiro, v. 276, p. 25-46, dez. 2017. Disponível em: <http://bibliotecadigital.fgv.br/ojs/index.php/rda/article/view/72991>. Acesso em: 29 de set. 2020. 
legitimados, notadamente Ministérios Públicos dos Estados (MPE), criaram disciplina normativa para tal, respondendo a algumas dessas questóes.

Iniciando pelo MP-SP, a Resolução n 1.193/2020-CPJ, de 11 de março de 2020, estabelece que a celebração de Acordo de Não-Persecução Cível exige a demonstração, pelas circunstâncias do caso concreto, de que a medida consensual promove o "pleno atendimento do interesse público". Ademais, dentre a matéria que pode ser transacionada pelos acordantes, não se incluem as penas de ressarcimento ao erário, perdimento de bens ou valores acrescidos ilicitamente ao patrimônio, e de, pelo menos, uma das sançóes previstas na Lei $\mathrm{n}^{\circ} 8.429 / 92$.

A resolução adota como pressuposto para o Acordo a demonstração da vantagem para o Interesse Público, considerando-se fatores como "a possibilidade de duração razoável do processo, a efetividade das sançóes aplicáveis e a maior abrangência de responsabilização" dos envolvidos. ${ }^{19}$

Outros aspectos importantes da resolução são a previsão de fase preliminar de tratativas, que poderão ser sigilosas. Os acordos firmados nessa fase pré-processual não poderão ser submetidos a controle jurisdicional. Além disso, nas negociações do Acordo de Não Persecução Cível a participação da pessoa jurídica interessada é facultada, no entanto, não se exige sua aquiescência como requisito de validade ou eficácia do acordo.

O MP-CE, ao tratar do tema na Nota Técnica n ${ }^{\circ} 001 / 2020^{20}$, estabeleceu roteiro prático de atuação, sem, no entanto, especificar condiçóes ou pressupostos para a realização do acordo. Ao tratar do cabimento, limites e cautelas no manejo desses acordos, o parquet cearense vale-se de uma interpretaçáo analógica com as disposiçóes acerca do Acordo de Não Persecução Criminal. A Nota, inspirada em documentos normativos congêneres, adota como regra a aplicação das sanções de reparação ao erário e a devolução dos valores ilicitamente acrescidos ao patrimônio, de modo que os Acordos poderiam ter como objeto o pagamento da multa civil; o compromisso de não contratar com o Poder Público; e o compromisso de reparação de danos morais coletivos.

Há no documento disposição acerca da pena de perda de cargo ou função pública, no seguinte sentido: "conforme negociado, pode constar a clausula da renúncia ou exoneração - mas o inadimplemento somente acarretará a rescisão do Acordo e a impetração da Ação Judicial (o que deverá constar explicitamente do Termo).”. Ademais, para o MP-CE "A suspensão dos direitos políticos não pode ser, portanto, avençada no acordo de não persecução cível.". Quanto à sanção de inelegibilidade, a Nota entende possível a estipulação de compromisso voluntário de que o sujeito ativo não concorra a mandato eletivo, mas não admite que o Acordo preveja condição de inelegibilidade.

Seguindo a mesma lógica de separação entre sanções que podem e as que não podem ser

19 SÃO PAULO. Ministério Público Estadual. Resoluçáo no 1.193/2020-CPJ, de 11 de março de 2020.

20 CEARÁ. Ministério Público Estadual. Centro de apoio operacional da defesa do patrimônio público e da moralidade administrativa - CAODPP. Nota Técnica ${ }^{\circ}$ 01/2020. 
objeto do Acordo de não-Persecução, o MP-PI ${ }^{21}$ e o MP-PE ${ }^{22}$, definem como obrigatórias: a confissão da conduta; a cessação pelo sujeito ativo; e o compromisso de reparação integral e restituição do produto do enriquecimento ilícito. São facultativas, por sua vez, as seguintes cominações: multa civil; proibição de contratar com o poder público ou receber benefício ou incentivo fiscal e creditício; reparação de dano moral coletivo; núncia da função pública; renúncia ao direito de se candidatar a cargos públicos eletivos. Interessante notar que as duas instituiçóes preveem a possibilidade de imposição de obrigaçóes mitiguem o risco de ocorrência de novos atos lesivos, como requisito obrigatório no MP-PE e facultativo no MP-CE.

Por fim, o MPE da Bahia regulou a matéria por meio da publicação de orientaçóes que tratam do tema ${ }^{23}$, e, resumidamente: não impóe como obrigatória nenhuma das sanções previstas da Lei $\mathrm{n}^{\circ}$ 8.429/92 considera facultativa a confissão pelo sujeito ativo; determina a aplicação das regras do microssistema de tutela coletiva ao procedimento do Acordo; autoriza sua celebração em sede judicial ou extrajudicial; exige a existência de elementos de convicção suficientes ao ajuizamento da ACP por improbidade para a celebração do Acordo; a celebração do Acordo interrompe o prazo prescricional; $\mathrm{O}$ direito ao acordo não constitui direito subjetivo do investigado; não é possível o estabelecimento da pena de suspensão dos direitos políticos; é possível a previsão de renúncia ao cargo público; a participação da pessoa lesada é obrigatória, sob pena de nulidade do Acordo.

\section{CONSIDERAÇÓES FINAIS}

As considerações apresentadas, por certo, não têm a pretensão de oferecer solução para a situação identificada. Mesmo porque, se pensamos que as dificuldades verificadas na celebração de acordos decisórios são decorrência de elementos centrais de nosso modelo democrático - como a pluralidade de bens protegidos pelo interesse público e a larga possibilidade de controle sobre a Administração - é evidente que não se pode pensar em qualquer tipo de solução simplista, voltada a afastar os elementos problemáticos do cenário.

Nesse sentido, parece até mesmo descabido falar em "solução", termo muito associado à ideia de que qualquer situação conflituosa pode ser reorganizada rumo a um modelo ideal. A vida em sociedade, o Estado, as instituiçóes públicas e a própria democracia não se aproximam de modelos ideias, mas sim de um movimento dinâmico e constante de conflito entre teses e construção de sínteses.

Se, por um lado, não é possível oferecer soluções grandiosas, por outro lado, o que pode ser feito - e que, para os operadores do direito, trata-se muito mais de um dever do que propriamente de mera faculdade - é influir para que as sínteses produzidas em torno de ques-

\footnotetext{
21 PIAUÍ. Ministério Público Estadual. Colégio de Procuradores de Justiça. Resoluçáo CPJ/PI No 04, de 17 de agosto de 2020.

22 PERNAMBUCO. Ministério Público Estadual. Conselho Superior do Ministério Público. Resolução $\mathrm{n}^{\circ} 01 / 2020$.

23 BAHIA. Ministério Público Estadual. Centro de Apoio às promotorias de Proteção à Moralidade Administrativa. Orientaçóes n ${ }^{\circ} 01$ a 22 de 2020.
} 
tóes concernentes ao debate público levem em consideração o maior número de aspectos e visôes possíveis, contribuindo para que a atividade do Estado esteja sempre direcionada à valorização dos preceitos fundamentais estabelecidos no documento constitucional.

É nesse contexto que este artigo, em síntese conclusiva, reconhece a inviabilidade de soluçôes amplas e globais para a questão apresentada, mas tenta chamar a atenção para a necessidade de que o debate quanto a coordenação de competência para acordos decisórios, no tocante a infraçóes contra a Administração, seja pensado também à luz das formas de aperfeiçoamento desse instrumento, incrementando sua efetividade e potencialidades.

Especialmente no momento em que esses imbróglios começam a chegar a Cortes Superiores - conforme mencionado na primeira parte do texto, o STF foi chamado a decidir sobre esse tema em um conjunto de Mandados de Segurança, ainda em julgamento -, é preciso que racionalidade das decisóes judiciais leve em conta a mensagem que isso transmite aos agentes econômicos, servindo de incentivo ou desincentivo a posturas colaborativa com o Poder Público na repressão a infrações contra a Administração.

Nosso cenário atual demonstra uma iniciativa clara de valorização dos instrumentos consensuais de resolução de conflitos, inclusive com a substituição de sançóes unilaterais aplicadas pelo Estado por formas colaborativas de reparação de danos causados ao interesse público. Exemplo disso são as previsóes de acordo de leniência na Lei de Defesa da Concorrência e na Lei Anticorrupção, além da recente inserção, na Lei de Improbidade Administrativa, da possibilidade de celebração de Acordo de Não Persecução Cível.

Essas iniciativas, no entanto, estão condenadas ao destino de natimortos se não forem acompanhadas de efetivas providências para a sua aplicação de forma previsível, objetiva e clara. Vale aqui dizer que a substituiçáo do paradigma sancionador unilateral do Estado por um modelo cooperativo resulta, dentre outras razóes, da constatação de falência desse último modelo, que, na experiência recente de nossa República pós-redemocratização, náo parece ter sido idônea para refrear um movimento de constantes violaçóes ao patrimônio público.

Em suma, quando falamos em assegurar condições favoráveis à celebração dos Acordos Decisórios, tratamos, em última análise, de dar um novo passo rumo a formas modernas de proteção da coisa pública, motivo pelo qual ignorar esse debate é condenar nossa sociedade a reproduzir um padrão ultrapassado de tutela da ordem jurídica.

\section{REFERÊNCIAS}

ARAÚJO, Aldem Johnston Barbosa. "Acordo de não persecução cível; primeiras impressóes". 2020. Migalhas, Ribeirão Preto, 19 de março de 2020. Disponível em: < https://www.migalhas. com.br/depeso/322104/acordo-de-nao-persecucao-civel-primeiras-impressoes $>$. Acesso em: ?

ATHAYDE, Amanda. Manual dos Acordos de Leniência no Brasil: teoria e prática. Belo Horizonte: Fórum, 2019.

BAHIA. Ministério Público Estadual. Centro de Apoio às promotorias de Proteção à Moralidade 
Administrativa. Orientaçóes n ${ }^{\circ} 01$ a 22 de 2020. Disponível em: http://infomail.mpba.mp.br/wpcontent/uploads/2020/03/enunciados-acordo-de-n $\% \mathrm{C} 3 \% \mathrm{~A} 3$ o-persecu $\% \mathrm{C} 3 \% \mathrm{~A} 7 \% \mathrm{C} 3 \% \mathrm{~A} 3 \mathrm{o}-$ c\%C3\%ADvel-2.pdf. Acesso em: 29.02.2020.

BRASIL. [Constituição (1988)]. Constituição da República Federativa do Brasil. Brasília, DF: Senado Federal: Centro Gráfico, 1988

Lei no 8.429, de 2 de junho de 1992. Diário Oficial da União, Brasília, DF.

. Lei no 13.964, de 24 de dezembro de 2019. Diário Oficial da União, Brasília, DF.

. Lei no 12.850/2013, de 2 de agosto de 2013. Diário Oficial da União, Brasília, DF.

. Lei no 12.846/2013, de $1^{\circ}$ de agosto de 2013. Diário Oficial da União, Brasília, DF.

. Lei no 12.529/2011, de 30 de novembro de 2011. Diário Oficial da União, Brasília, DF.

. Lei no 13.506/2017, de 13 de novembro de 2017. Diário Oficial da União, Brasília, DF.

Lei no 13.105/2015, de 16 de março de 2015. Diário Oficial da União, Brasília, DF.

. Lei no 7.437/1985, de 20 de dezembro de 1985. Diário Oficial da União, Brasília, DF.

Lei no 9.099/1995, de 26 de setembro de 1995. Diário Oficial da União, Brasília, DF.

. Lei no 7.347/1985, de 24 de julho de 1985. Diário Oficial da União, Brasília, DF.

. Lei no 8.078/1990, de 11 de setembro de 1990. Diário Oficial da União, Brasília, DF.

Lei no 9.307, de 23 de setembro de 1996. Dispóe sobre a arbitragem. Diário Oficial da União, Brasília, DF.

. Supremo Tribunal Federal (Tribunal Pleno). ADI 4764. Relator: Min. Celso De Mello, Relator p/ Acórdão: Roberto Barroso, julgado em 04/05/2017, DJe-178 em 15/08/2017.

. Supremo Tribunal Federal (2. Turma). MS 35435/DF, MS 36496/DF, MS 36526/DF e MS 36173/DF, Relator: Min. Gilmar Mendes, em 26/05/2020. DJe-138 em 03/06/2020.

Supremo Tribunal Federal (Tribunal Pleno). Ação Direta de Inconstitucionalidade 3.943/DF Relatora: Cármen Lúcia, em 07/05/2015, DJe-154 em 06/08/2015.

Superior Tribunal de Justiça (3. Turma). REsp 904.813/PR. Rel. Ministra Nancy Andrighi, julgado em 20/10/2011, DJe em 28/02/2012.

CEARÁ. Ministério Público Estadual. Centro de Apoio Operacional da Defesa do Patrimônio Público e da Moralidade Administrativa - CAODPP. Nota Técnica $\mathbf{n}^{\circ}$ 01/2020. Disponível em: < http://www.mpce.mp.br/wp-content/uploads/2020/02/11fev20_CAODPP_nota-tecnicaacordo-n\%C3\%A3o-persecu\%C3\%A7\%C3\%A3o-civel.pdf>. Acesso em: 29.02.2020.

CUNHA, Leonardo Carneiro da. A Fazenda Pública em juízo. Rev., atual e ampl. Rio de Janeiro: Forense, 2017.

DE SÁ, Acácia Regina Soares. "O acordo de não-persecução civil na ação de improbidade administrativa". 2020. Disponível em: < https://www.tjdft.jus.br/institucional/imprensa/ artigos-discursos-e-entrevistas/artigos/2020/o-acordo-de-nao-persecucao-civil-na-acao- 
de-improbidade-administrativa\#: - : text $=\mathrm{O} \% 20$ acordo $\% 20$ de $\% 20 \mathrm{n} \% \mathrm{C} 3 \% \mathrm{~A} 3 \mathrm{o} \% 20$ persecu $\%$ C3\%A7\%C3\%A3o,de\%20tornar\%20mais\%20c\%C3\%A9lebre\%20e>. Acesso em 10.07.2020.

DI PIETRO, Maria Sylvia Zanella. Direito Administrativo. 27. ed. São Paulo, Atlas: 2014.

FERRAZ, Luciano. "Acordos de náo persecuçáo na improbidade administrativa - o início, o fim e o meio". 2020. Disponível em: < https://www.conjur.com.br/2020-abr-09/interessepublico-acordos-nao-persecucao-civel-improbidade-administrativa>. Acesso em 10.07.2020.

FREITAS, Juarez. Direito administrativo não adversarial: a prioritária solução consensual de conflito. Revista de Direito Administrativo, Rio de Janeiro, v. 276, p. 25-46, dez. 2017. Disponível em: <http://bibliotecadigital.fgv.br/ojs/index.php/rda/article/view/72991>. Acesso em: 29 de set. 2020.

MELLO, Celso Antônio Bandeira de. Curso de direito administrativo. São Paulo: Malheiros. 2012.

MOREIRA NETO, Diogo de Figueiredo. Curso de direito administrativo. Rio de janeiro: Forense, 2005. V. 15.

OLIVEIRA, Fernando Andrade de. Conceituação do direito administrativo. Revista de Direito Administrativo, Rio de Janeiro, v. 121, p. 16-57, dez. 1975. ISSN 2238-5177. Disponível em: <http:// bibliotecadigital.fgv.br/ojs/index.php/rda/article/view/41476/40218>. Acesso em: 10 jul. 2020.

OLIVEIRA, Rafael Carvalho Rezende. Curso de Direito Administrativo: Rio de Janeiro. Método, 2020.

OSÓRIO, Fábio Medina. Natureza jurídica do instituto da náo persecuçáo cível previsto na lei de improbidade administrativa e seus reflexos na lei de improbidade empresarial. 2020. Disponível em: https://www.migalhas.com.br/depeso/321402/natureza-juridica-do-institutoda-nao-persecucao-civel-previsto-na-lei-de-improbidade-administrativa-e-seus-reflexos-na-lei-deimprobidade-empresarial. Acesso em: 29. set. 2020.

PERNAMBUCO. Ministério Público Estadual. Conselho Superior do Ministério Público. Resoluçáo no 01/2020. Disponível em: < https://www.mppe.mp.br/mppe/institucional/conselhosuperior/conselho-instrumentos-juridicos/category/192-resolucoes $>$. Acesso em: 29.09.2020.

PIAUÍ. Ministério Público Estadual. Colégio de Procuradores de Justiça. Resoluçáo CPJ/PI No 04, de 17 de agosto de 2020. Diário eletrônico do MP-PI. ANO IV - No 700 Disponibilização: 19.08.2020. Publicação: 20.08.2020.

PIMENTA, Guilherme. Balcão único para negociar leniência pode não ser factível, diz especialista. Amanda Athayde Linhares, que coordenou programa de negociaçóes no Cade, lança livro sobre o tema. Portal JOTA, São Paulo, 10 abr. 2019. <https://www.jota.info/tributos-eempresas/mercado/empresa-leniencia-entrou-amanda-athayde-21062018>. Acesso em 10.07.2020.

SÃO PAULO. Ministério Público Estadual. Resolução no 1.193/2020-CPJ, de 11 de março de 2020. Diário Oficial do Estado de Sáo Paulo: Poder Executivo - Seção I, São Paulo, v.130, n.49, p.48, de 12 de março de 2020. 